\title{
III
}

\section{FAMÍLIA, CONTEMPORANEIDADE E CONSERVADORISMO - UMA ATUALIZAÇÃO SOBRE O DIREITO DAS FAMÍLIAS ${ }^{* 1}$}

\author{
Juliana Maggi Lima
}

\section{Introdução}

Nos últimos anos, a família voltou a ser objeto de intensa disputa política. Forças pretensamente conservadoras se valem desse tema para mobilizar a população. A ilustrar essa afirmação, 2018 foi ano em que a família foi colocada em papel central da disputa presidencial. O então candidato à vice-Presidência Hamilton Mourão afirmou que famílias pobres e chefiadas por mulheres seriam fábricas de desajustados, que fornecem mão-de-obra para o tráfico (GIELOW, 2018). O candidato à Presidência, Jair Bolsonaro, por sua vez, assinou termo de compromisso de defender " [...] o verdadeiro sentido do Matrimônio, como união entre homem e mulher; - a Família constituída de acordo com o ensinamento da Igreja [...]”. (MACEDO, 2018).

Esse panorama, contudo, é de ser dito, é anterior à eleição presidencial de 2018. Jair Messias Bolsonaro, colocou-se nas eleições como um conservador (ainda que sua agenda presidencial de ataque à Igreja Católica e sua própria realidade pessoal - estar no terceiro casamento, por exemplo, não sejam necessari-

*DOI - 10.29388/978-65-86678-28-4-0-f.67-90

${ }^{1}$ Este capítulo foi escrito a convite da professora Eunice Teresinha Fávero, em função de artigo que escrevi dezembro de 2015, publicado em setembro de 2017, com o título "Família, contemporaneidade e conservadorismo - Direito das Famílias" (LIMA, 2017). A proposta era atualizar o mencionado artigo. Apesar do curto espaço de tempo desde que foi escrito (quatro anos), o tema segue ainda mais relevante, com mudanças significativas no campo político, com consequências para a esfera jurídica das famílias. Assim, este capítulo é uma atualização da mencionada publicação, com inclusão do aprofundamento de algumas reflexões sobre o conceito de família feitas na minha dissertação de mestrado, depositada em dezembro de 2018 e defendida em janeiro de 2019 na Faculdade de Direito da USP. Assim, este artigo segue a estrutura do mencionado capítulo, porém, atualizado e aprofundado.

${ }^{2}$ Bacharel em Direito pela PUC-SP, Especialista em Direito de Família e Sucessões pela EPD, mestre em Direito Civil pela USP, advogada sócia do escritório Dias, Brandão, Maggi Lima Sociedade de Advogados. 
amente condizentes com esse espectro) (LAGO, 2019; GALVANI, 2019; FONSECA, 2019), e pautou sua candidatura essencialmente na defesa da suposta família tradicional (formada por um homem e uma mulher) e contra direitos assegurados a minorias nos últimos anos. Mas, é de se dizer que ele apenas chegou com capital político para tanto após anos se alavancando a partir desse embate. $^{3}$ Sua pífia atuação como legislador foi esquecida em decorrência de seus posicionamentos agressivos e contrários a direitos das minorias (POTTER, 2018). Há posições de pessoas que estão no espectro político considerado progressista e no conservador que dizem que Bolsonaro apenas se vale dessa definição, sem de fato ser conservador.

Nesse contexto verifiquei, por meio da minha dissertação de mestrado, que até mesmo os textos jurídicos não refletiam integralmente o conceito tradicional de família. Segundo autores renomados do período, o conceito seria a válida união matrimonial formada pelo homem e pela mulher e sua prole. Contudo, verifiquei que apenas

[...] esses dois elementos (família matrimonial com necessária dualidade de gêneros), sozinhos, são insuficientes para explicar a família jurídica desde a Independência até a CF de 1988. Ao analisar o conceito jurídico de família com base nos demais aspectos jurídicos e históricos, fica demonstrado que apenas os católicos faziam jus à constituição de família e os negros, juridicamente, nem sequer eram considerados pessoas humanas, não possuindo direitos nem em relação a seus filhos, mesmo após a Lei do Ventre Livre. Se os negros, escravizados com fundamento no próprio ordenamento jurídico, não tinham direito sobre si ou seus filhos, presume-se que a lei da época, ao falar em família, continha implícito o entendimento de que apenas pessoas brancas poderiam formá-la reconhecidamente perante o Estado e a sociedade. (LIMA, 2018, p. 178).

Assim, entendo que o que vem sendo considerado como família tradicional não corresponde ao que de fato era a família brasileira em sua origem, sob a ótica jurídica. E demonstrada essa premissa, que foi uma das conclusões do meu estudo no mestrado, entendo que a família, enquanto instituição jurídica, já teve seu conceito tradicional original muito alterado. Isto é, o que hoje se defende ser família tradicional (casal formado por homem e mulher) não cor-

\footnotetext{
3 A título de exemplo, em 2011, disse em resposta à cantora Preta Gil, que jamais teria um filho gay, pois deu boa educação aos seus filhos, o que lhe rendeu processos judiciais e atenção da mídia (VEJA, 2019).
} 
responde ao efetivo conceito tradicional de família, que continha em si outras limitações e contornos.

Dentro do contorno inicial de família no ordenamento jurídico brasileiro, ela era: formada apenas entre católicos, uma instituição acessível apenas a pessoas brancas, matrimonial, indissolúvel e formada apenas com a dualidade de gênero. As quatro primeiras características não são mais essenciais ao conceito de família por escolha legislativa. Já a dualidade de gênero só foi superada por decisão judicial e segue sendo objeto de projetos de lei, a despeito de, como concluí em minha dissertação de mestrado, ser matéria que não é passível de alteração legislativa, o que explicarei melhor a seguir.

A discussão sobre quais tipos de grupos sociais merecem ser ou não reconhecidos como família é relevante na medida em que a família se revela como a principal formação social, sendo base da sociedade, merecedora de especial proteção do estado (art. 226, caput, da Constituição Federal). Tanto no artigo que deu origem a este texto quanto em minha dissertação de mestrado, parti da premissa que, a despeito (ou justamente) por sua relevância social (LIMA, 2018, p. 33) que a família não possui contornos absolutamente definidos (AZEVEDO, 2001, p. 297). É um grupo familiar que recebe proteção especial do Estado, com direitos e obrigações recíprocas dos indivíduos, mas sem que se esclareça exatamente quais seriam as formações sociais enquadradas nesse contexto.

A Constituição Federal - CF (BRASIL, 1988) regulamenta a família em seu Capítulo VII, intitulado "Da Família, da Criança, do Adolescente, do Jovem e do Idoso", (arts. 226-230). Tem especial importância na definição de família o disposto no caput do art. 226, que, como já dito, eleva a família a patamar de relevância na sociedade, mas deixa de defini-la ou de trazer contornos mínimos. Tampouco, se define qual seria a proteção especial conferida pelo Estado e como a família é a base da sociedade. Os elementos que encontramos nos demais dispositivos constitucionais sobre o tema pouco esclarecem, mas trazem alguns contornos, mas sem que haja efetiva definição.

Apesar disso, a Constituição de 1988 foi paradigmática para o conceito de família. Com esse texto constitucional, a família saiu da esfera do monopólio do matrimônio (art. 226, $\$ 3^{\circ}$ ), passou a poder ser constituída por apenas um dos pais - também chamada de monoparental (art. 226, $\$ 4^{\circ}$ ) e trouxe a igualdade jurídica entre homens e mulheres no exercício dos direitos e deveres conjugais (art. 226, $\int 5^{\circ}, \mathrm{CF}$ ).

Até então, por disposição constitucional expressa, desde 1934, a família era constituída exclusivamente pelo matrimônio (e até 1977 indissolúvel em 
vida) (LIMA, 2018, p. 61), havendo legislação infraconstitucional que garantia mais direitos ao homem que à mulher dentro da família. Com essas sensíveis alterações, ficou ainda mais evidente que esse núcleo especial em que o ser humano se desenvolve e recebe cuidados especiais quando vulnerável (em fase de desenvolvimento ou de degeneração) é fluido, com transformações que acompanham a sociedade na qual está inserida, sendo que o direito deve perseguir a regulamentação dessas novas formações quando já largamente parte da realidade social (CRUET, 1908, p. 81). ${ }^{4}$

Atualmente, o que chamamos de família pós-moderna tem suas bases no sistema econômico capitalista, pautado em lógica individualista, com reflexos nos próprios núcleos familiares, que estão cada vez menores, aos quais são atribuídas diversas funções que poderiam ser exercidas pelo Estado. ${ }^{5}$ A família é, portanto, uma forma de desonerar o Estado com obrigações com os indivíduos e em seu debate é imprescindível pensar para além de questões como a dualidade de gênero, como se vem fazendo nos últimos anos no Brasil, temos desafios relevantes, como o envelhecimento da população e as relações e direitos e obrigações intergeracionais (LIMA, 2018, p. 38).

As profundas mudanças jurídicas pelas quais o conceito de família passou no século XX foram decorrentes das profundas alterações sociais que aconteceram. A existência de duas Guerras Mundiais, alterando a lógica da geopolíti-

\footnotetext{
${ }^{4}$ Não apenas no Brasil, mas em outros países, ao longo do século XX houve relevantes mudanças sobre o conceito de família. Em meu mestrado, apresentei algumas delas, sendo parte pela via legislativa e parte pela judicial. Destaco entre elas o julgamento da Suprema Corte dos Estados Unidos sobre a possibilidade de casamento inter-racial (Loving vc Virginia, de 1967), o reconhecimento pela mesma Corte de que o direito a casar não está condicionado ao comprometimento com a intenção de procriar ou possibilidade biológica disso (Obergefell vs. Hodges), a alteração do Código Civil espanhol de 2005 que passou a permitir o casamento entre pessoas do mesmo gênero, entre outros. (LIMA, 2018, p. 114 e seguintes)

5 "Em contraste com o modelo universal, o chamado modelo liberal prioriza o mercado e a família. Nesse modelo, também denominado de "residual" ou tradicional, a provisão de serviços sociais se faz mais fortemente no âmbito do mercado, cabendo ao Estado um papel subsidiário. O modelo conservador, inclusive de inspiração católica, coloca a provisão no âmbito da família ou da ajuda social. [...] No entanto, no contexto capitalista atual, sob a ótica do neoliberalismo, há fortes pressões do capitalismo mundial para abrir os mercados (globalização) às empresas multinacionais, reduzir o papel do Estado, transferir responsabilidades do Estado para o mercado e a família, fazendo com que a cidadania seja confinada. A cidadania confinada é a limitação das titularidades a um grupo, a um tempo determinado ou a condições de atividade e trabalho.” (FALEIROS, 2008, p. 565). A mudança na constituição demográfica da população tem grandes impactos nas famílias e que terão impactos também na ordem jurídica das famílias.
} 
ca, a mudança dos conceitos de gênero, a mudança demográfica e o envelhecimento da população, as inovações tecnológicas, por exemplo, fizeram com que a sociedade como um todo se modificasse e isso teve grande impacto nas famílias (LIMA, 2018; SARACENO; NALDINI, 2013).

Em decorrência dessas mudanças, o direito internacional também tratou das famílias. Há alguns instrumentos jurídicos internacionais que regulamentam as famílias, mas, entre os mais, se não o mais importante, está a Declaração Universal dos Direitos do Homem, de 1948, que reconhece a família como "[...] elemento natural e fundamental da sociedade e tem direito à proteção desta e do Estado" (art. 16.3). O contexto em que a Declaração surgiu foi no pós-guerra, com estados absolutamente combalidos, sem condições de exercer os cuidados básicos com os cidadãos, que passaram a ser de responsabilidade principal da família. ${ }^{6}$

A família (e nesse contexto falamos em termos de Brasil), contudo, antes de ser núcleo de apoio para o pleno desenvolvimento do ser humano, era, essencialmente, uma instituição regida por dogmas Católicos $^{7}$ e com fim em si mesma, além de ser meio de manutenção de patrimônio em um mesmo tronco familiar, era meio de submissão das mulheres aos homens.

Podemos afirmar que, no Brasil, a família era um fim em si mesma na medida em que até 1977 ela era indissolúvel em vida, formada pelo matrimônio, que só poderia ser dissolvido pela morte. Os casais, por mais infelizes que fossem entre si, eram obrigados a permanecer unidos como família, sendo mais importante a manutenção da instituição do que a felicidade ou o bem-estar de seus indivíduos.

Além disso, as demandas sociais trouxerem novos formatos juridicamente admitidos como aptos a formarem essa estrutura assim socialmente reconhecida, como as famílias homoafetivas ${ }^{8}$ (já definitivamente reconhecidas

6 "Apesar de a Constituição Federal dividir entre família, sociedade e estado a responsabilidade pelos indivíduos, é a família o local primordial de cuidado e não coincidentemente é colocada em primeiro lugar no texto constitucional nos art. 227, 229 e 230. A responsabilidade pela assistência mútua é conferida inicialmente à família também pela legislação infraconstitucional, como no Código Civil, art. 1.694 e Estatuto da Criança e do Adolescente, art. 19.

${ }^{7}$ A importância da religião na família é longamente descrita por diversos autores, tal como Fustel de Coulanges, para quem a "religião foi o princípio constitutivo da família antiga". Não que a família tenha sido criada pela religião, mas foi esta que lhe deu normas e um formato específico. (COULANGES, 1961, p. 51).

${ }^{8}$ O termo homoafetivo surgiu nos anos 2000 , sendo sua criação atribuída por diversos autores a Maria Berenice Dias, termo com o qual buscou destacar os vínculos de afeto entre esses casais e retirar o estigma de promiscuidade ligado aos homossexuais, 
como existentes pelo Supremo Tribunal Federal, no julgamento da ADI 4277 da ADPF 132), a filiação sociafetiva e multiparentalidade, ambas também já aceita de forma majoritária pela doutrina e pela jurisprudência $)^{9}$ e as uniões paralelas e as relações poliafetivas (essas duas ainda não pacificamente admitidas). ${ }^{10}$

Entre os novos paradigmas da constituição de família e dos vínculos de parentesco, o mais relevante e mencionado, seja pela doutrina ${ }^{11}$, seja pela jurisprudência $^{12}$, é o afeto. Esse termo, que vem sendo utilizado por grande parte dos juristas, pouco era considerado na definição de família até o início do século XX, pois ela possuía caráter juridicamente patrimonial, patriarcal, religioso, com fins de reprodução (PONTES DE MIRANDA, 1917). Esse foi um dos elementos repetido por diversas vezes na jurisprudência que analisei na dissertação de mestrado,

especialmente homens. O termo foi largamente adotado pela doutrina e jurisprudência, inclusive pelo STF, por exemplo, no julgamento da ADI 4277.

9 Vide Tese em Repercussão Geral 622 aprovada pelo STF em 2016: “A paternidade socioafetiva, declarada ou não em registro público, não impede o reconhecimento do vínculo de filiação concomitante baseado na origem biológica, com os efeitos jurídicos próprios".

${ }^{10}$ Segundo os contrários às famílias paralelas, o princípio da monogamia é princípio do direito de famílias. Nas hipóteses em que vem se admitindo o reconhecimento das famílias paralelas, esse se pauta na proteção àqueles que durante muitos anos agiram como família e assim se reconheciam, a despeito da existência de uma das partes, via de regra o homem, ter, paralelamente, outra família, matrimonial ou reconhecida como união estável). O Supremo Tribunal Federal já reconheceu a existência de repercussão geral no Recurso Extraordinário (RE) 1045273, em caso que trata da possibilidade de uniões concomitantes para fins de divisão de benefício previdenciário. Atualmente, oito ministros já votaram. O Relator, Alexandre de Moraes, votou no sentido de afastar a possibilidade de reconhecimento de duas uniões simultâneas e foi acompanhado pelos Ministros Ricardo Lewandowski e Gilmar Mendes. O Ministro Edson Fachin abriu divergência reconhecendo a possibilidade de existência de uniões estáveis simultâneas, se houvesse boa-fé objetiva, isto é, sem que a pessoa não soubesse da existência da outra união mantida pelo companheiro. Acompanharam o Ministro Fachin os Ministros Luís Roberto Barroso, Rosa Weber, Cármen Lúcia e Marco Aurélio. Após esses votos, que foram proferidos em setembro de 2019, o Ministro Dias Toffoli pediu vista dos autos e até o momento não devolveu para retomada do julgamento.

${ }^{11}$ Nesse sentido Paulo Lôbo (2015, p.118) e Rolf Madaleno (2015, p.104)

12 Esse conceito, ainda que usado de forma genérica, sem conceituação jurídica consagrada do termo, foi, por exemplo, elemento fundamental no reconhecimento das uniões homossexuais pelo STF e é o pilar da filiação socioafetiva, nova forma de origem desse vínculo, que não se dá por fatores biológicos ou de adoção, mas pelo cuidado mútuo e no reconhecimento entre as pessoas e perante a sociedade desse vínculo. O tema será abordado de forma mais aprofundada adiante. 
[...] não há definição do que seria afeto e afetividade e se são sinônimos ou não. Esses termos, tão recorrentemente utilizados pelos ministros, passaram a ser conceitos bastante abertos, indefinidos. Segundo a análise doutrinária apresentada, está se consolidando a noção de afeto ou afetividade enquanto princípio norteador do direito de família, mais do que enquanto direito conferido e exigível de seus membros, que se confundiria com os deveres de cuidado inerentes à família. (LIMA, 2018, p. 185)

As mudanças sociais historicamente rápidas e profundas na sociedade tiveram impacto direto na formação da família, em especial a partir da segunda metade do século XX. Para compreendê-las, apresento algumas das principais mudanças jurídicas relativas ao conceito, no período.

\section{A Família no ordenamento jurídico Brasileiro}

Como dito, ainda que historicamente utilizemos o termo família para designar o conjunto de pessoas ligadas por vínculos de parentesco decorrentes do válido matrimônio, o conceito passou por profundas alterações de forma particularmente célere desde o início do século XX, acompanhando as mudanças sociais do período, ainda que sem perder alguns de seus contornos considerados tradicionais.

Com o passar do tempo, a relevância da religião na família passou a ser mitigada, mas foi mantida a importância dos valores religiosos, como a importância da prole ${ }^{13}$ e a submissão da mulher ao homem, o que se atribui à grande influência da Igreja, por meio da interpretação de passagens bíblicas.

Especificamente no Brasil, desde a Colônia até após a Independência, o ordenamento jurídico brasileiro seguia as Ordenações Filipinas ${ }^{14}$, com suas diversas modificações. A importância da Igreja se mostrava relevante nas Ordenações, que em diversos momentos trazia previsões legais a ela relacionadas, com-

\footnotetext{
13 Além dos motivos religiosos, a prole era economicamente importante "Os filhos eram, na visão de todos, bons investimentos, e como tal eram saudados. Quanto mais, melhor. Além disso, dizia a voz da razão, era uma aposta: a expectativa de vida era curta e todos se perguntavam se o recém-nascido viveria o suficiente para que suas contribuições à renda familiar pudessem se fazer sentir." (BAUMAN, 2004, p. 28).

${ }^{14}$ Compilação de normas que vigorou em Portugal de 1603 até o século XIX (com diversas modificações no período) e continuou a ser aplicada no Brasil, mesmo após sua revogação em Portugal.
} 
ferindo validade jurídica a seus atos ${ }^{15}$.

Apenas em 1861 é que foi permitido efeitos civis de casamentos realizados entre pessoas de outras fés (Decreto 1.144, de 11 de setembro de 1861. BRASIL, 1861 $)^{16}$

[...] desde que não existentes impedimentos com as leis em vigor e com o casamento católico [...]. Com a queda do Império, em 1889, e a consequente ascensão dos princípios republicanos, no ano seguinte ocorreu a separação entre Estado e Igreja, por meio do Decreto 119-A/1890. No mesmo ano foi promulgado o Decreto 181/1890, que instituiu o casamento civil e também trouxe uma figura jurídica chamada divórcio, elaborado com base no direito canônico, mas que se aproximava mais do desquite e da separação judicial do que do divórcio, apto a dissolver o casamento, como hoje entendemos. Após a promulgação da Constituição de 1891, houve a instituição definitiva do casamento civil, que passou a ser não apenas regra, mas a única forma de casamento reconhecida pelo Estado até 1934 (AZEVEDO, 2001, p. 153-154): “Art. 72: [...] \ $4^{\circ} \mathrm{A}$ Republica só reconhece o casamento civil, cuja celebração será gratuita”. Contudo, a noção de casamento continuava colada ao conceito religioso.”. (LIMA, 2018, p. 58).

A revogação das Ordenações Filipinas no Brasil se deu com a vigência do Código Civil de 1916 (CC 1916). Nesse Código falava-se no direito de uma família: a matrimonial, patriarcal, com objetivo de procriação, cujos descendentes eram presumidamente ligados por vínculos biológicos com o casal que deu origem à unidade por meio do matrimônio (art. 229, do CC 1916: Criando a família legítima, o casamento legitima os filhos comuns, antes dele nascidos ou concebidos (art. 352-354)).

Nesse contexto, o conceito de família era a unidade formada por um homem e uma mulher, unidos pelo vínculo do matrimônio, e sua prole. O Livro I da Parte Especial do Código Civil de 1916 - Do Direito de Família - iniciava-se com diversas disposições relativas ao casamento (celebração, impedimentos, regime de bens, regime dotal, entre outros) e, como acima transcrito,

\footnotetext{
${ }^{15}$ Cf. Ordenações Filipinas Livro I, título I (O Regedor da Casa de Suplicação deveria eleger um sacerdote para que antes do trabalho com os desembargadores fosse rezada uma missa) e Livro IV, título XLVI (previa o casamento na Igreja).

${ }^{16}$ Ressalte-se que decorridos mais de 125 anos da Proclamação da República, ainda se admite a possibilidade de casamento religioso com efeito civil (art. 1.515 e 1.516 do Código Civil de 2002).
} 
estabelecia que o casamento criava a família e legitimava os filhos do casal, nascidos antes ou depois do casamento, não trazendo qualquer outra forma de criação de uma família.

A representação, liderança da família era conferida legalmente ao marido (caráter patriarcal), o que foi alvo de mudanças legislativas ao longo dos anos. Segundo o texto original do CC 1916, o homem era o chefe da família, o que foi posteriormente mitigado com a previsão da colaboração da mulher nesse exercício ${ }^{17}$ até ser juridicamente extinta essa distinção na liderança da família pela CF 1988 (art. 226, \5 50. BRASIL, 1988).

A relevância patrimonial dessa união era tamanha, que até mesmo o regime dotal era regulado, sendo destinado um capítulo inteiro sobre o tema no texto original do CC 1916 (artigos 278 e seguintes) (BRASIL, 1916).

O parentesco, por sua vez, dividia-se em legítimo e ilegítimo, conforme a origem do vínculo fosse matrimonial ou não. ${ }^{18}$

A definição rígida do conceito de família do texto original do Código Civil de 1916 passou a ser mitigada ao longo do século XX, com alterações legislativas, significativas.

Entre as leis mais relevantes aprovadas pelo Congresso Nacional no período anterior à promulgação da Constituição de 1988 estão o Estatuto da Mulher Casada (Lei 4.121/1962) ${ }^{19}$ e a Emenda Constitucional 9/1977, que instituiu o divórcio, seguida pela Lei do Divórcio. O divórcio só se tornou uma realidade jurídica no Brasil em 1977, mas esse é um debate que remonta ao final do século XIX. (LIMA, 2018, p. 60).

A relevância da indissolubilidade do casamento, decorrente de preceito religioso, era tamanha em nosso ordenamento jurídico que estava prevista nas Constituições de $1934^{20}$ e de $1967^{21}$, o que demonstra seu impacto na sociedade

17 Redação original do Art. 233 do Código Civil de 1916: O marido é o chefe da sociedade conjugal. Redação modificada pela Lei 4,121/62, que passou a ser Art. 233. O marido é o chefe da sociedade conjugal, função que exerce com a colaboração da mulher, no interesse comum do casal e dos filhos (art. 240, 247 e 251).

18 Art. 332, CC 1916: O parentesco é legitimo, ou ilegítimo, segundo procede, ou não de casamento; natural, ou civil, conforme resultar de consanguinidade, ou adoção

${ }^{19}$ Até a promulgação do Estatuto da Mulher Casada, a mulher que se casasse se tornava civilmente incapaz, tinha que pedir autorização do marido até mesmo para aceitar herança e exercer profissão, conforme redação original dos art. $6^{\circ}$ e 242 do Código Civil de 1916.

20 Art 144 - A família, constituída pelo casamento indissolúvel, está sob a proteção especial do Estado

21 “Art. 167 - A família é constituída pelo casamento e terá direito à proteção dos Poderes Públicos: \ $1^{\circ}$ - O casamento é indissolúvel." Como o casamento era 
brasileira.

A Lei do Divórcio auxiliou na emancipação da mulher e rompeu com o preceito católico da indissolubilidade do casamento, ainda que o divórcio tivesse que ser precedido por lapso de tempo de separação judicial (dois anos) ou de fato (cinco anos), permitindo que as pessoas que haviam sido casadas constituíssem novas famílias sem que a nova prole fosse prejudicada pelo estado civil de seus pais.

\subsection{A Constituição Federal de 1988 - Pluralidade de famílias}

A mais relevante contribuição legislativa para o avanço do direito das famílias brasileiras no século XX foi a Constituição de 1988, tanto pela parte em que expressamente trata do tema, quanto pelos princípios e direitos fundamentais previstos nela, que permitiram fundamentar as mencionadas demandas sociais envolvendo direitos de família (LÔBO, 2011, p. 17).

Em contraponto ao conceito tradicional de família, a Constituição de 1988 BRASIL, 1988) trouxe novos parâmetros para o conceito: despatrimonializada, com igualdade entre cônjuges e companheiros, igualdade entre diferentes tipos de família, plena igualdade entre filhos, independentemente da origem, atribuição de direitos e deveres aos filhos, que passaram a ser definitivamente seres de direito.

A família deixou de ser entidade com um fim em si mesma e passou a ser um meio para o pleno exercício da personalidade de cada um de seus membros (FARIAS; ROSENVALD, 2011).

Apesar da inquestionável importância e vanguarda na proteção e ampliação do conceito de família, a Constituição Federal (BRASIL, 1988) possui 250 artigos, sendo que ao tema são destinados apenas cinco (arts. 226-230) de forma não exclusiva, visto que estão incluídos no Capítulo "Da Família, da Criança, do Adolescente, do Jovem e do Idoso".

Deste modo, de pronto se percebe que o texto não exaure as questões sobre o tema, mas ao menos rompe com a hegemonia do modelo matrimonial

indissolúvel em razão de preceito constitucional, antes da provação da Lei do Divórcio, a Constituição de 1967 foi alterada para que se permitisse a dissolução do casamento, sendo que o art. 175 desse texto foi objeto da inclusão do parágrafo primeiro - por meio da emenda constitucional $\mathrm{n}^{\circ} 9 / 77$ - $\$ 1^{\circ}$ O casamento somente poderá ser dissolvido, nos casos expressos em lei, desde que haja prévia separação judicial por mais de três anos) 
de família, reconhecendo, por exemplo, a família monoparental, isto é, aquela formada por qualquer dos pais e seus filhos. ${ }^{22}$

Com a nova Constituição iniciou-se um novo momento do direito de família, com surgimento da noção de 'direito das famílias', termo que “[...] melhor atende a necessidade de enlaçar, no seu âmbito de proteção, as famílias, todas elas, sem discriminação, sem preconceitos" (DIAS, 2011, p. 28).

Entre as disposições constitucionais que influenciam o direito das famílias devem ser destacadas a dignidade da pessoa humana (fundamento da República Federativa do Brasil, art. $1^{\circ}$, III), os objetivos fundamentais da República de construção de sociedade livre, justa e igualitária (art. $3^{\circ}$, I) e de promoção do bem de todos, sem preconceitos de origem, raça, sexo, cor, idade e quaisquer outras formas de discriminação (art. $3^{\circ}$, IV) e a prevalência dos direitos humanos (art. $4^{\circ}$, II). (BRASIL, 1988)

Merecem destaque também os direitos fundamentais, previstos de forma expressa, mas não exaustiva no artigo $5^{\circ}$ da Constituição Brasileira, como o da igualdade, da inviolabilidade da intimidade e da vida privada ${ }^{23}$.

\subsection{Código Civil de 2002}

Diante da ausência de conceitos constitucionais definitivos sobre família, houve crescimento da importância da legislação infraconstitucional, que deve ser interpretada de acordo com a Constituição, seja pelos cinco artigos que estão no Capítulo dedicado à família, seja de acordo com os demais dispositivos constitucionais, especialmente os princípios (arts. $1^{\circ}$ a $4^{\circ}$ ) e direitos fundamentais $\left(\operatorname{art.} 5^{\circ}\right)$. Assim, o conceito de família se ampara não apenas nos ditames da Constituição, mas também na legislação infraconstitucional. (BRASIL, 2002)

Em 2002, foi promulgado o atual Código Civil brasileiro (Lei $10.406 / 2002)$, cujo projeto de lei tramitou por quase trinta anos no Congresso Nacional, sendo considerado como uma lei que nasceu já ultrapassada, apesar de se tratar de uma das leis mais relevantes de nosso ordenamento jurídico, por sua abrangência e aplicação.

\footnotetext{
22 Art. 226, $\sqrt{ } 4^{\circ}$ : Entende-se, também, como entidade familiar a comunidade formada por qualquer dos pais e seus descendentes)

${ }_{23}$ É de se destacar que apesar do avanço constitucional de romper com a predominância da característica patrimonial da família, a Constituição de 1988 ainda traz resquício da patrimonialização da família ao incluir entre os direitos fundamentais o direito de herança (art. $\left.5^{\circ}, \mathrm{XXX}, \mathrm{CF}\right)$
} 
O longo período de tramitação permitiu uma série de emendas que deixaram o texto com algumas contradições e desconectado com o seu tempo. Mesmo após o advento da Constituição, em 1996 o projeto ainda trazia termos já abolidos, como filhos ilegítimos (PEREIRA, 1996), sendo que grande parte desses anacronismos (ou melhor, inconstitucionalidades) foi objeto de emendas e suprimida até a efetiva promulgação do Código Civil de 2002.

O CC 2002 dedicou o Livro IV da Parte Especial ao Direito de Família, sendo que a importância do casamento foi mantida, destacando-se em relação às demais formações familiares, visto que o livro se inicia com as disposições relativas ao casamento, estendendo-se sobre o tema do art. 1.511 ao 1.582 (dos quais grande parte conta com diversos parágrafos e incisos).

O caráter conservador do CC 2002 também se mostra ao tratar de forma discriminatória os filhos havidos fora do casamento ${ }^{24}$, ao trazer um capítulo inteiro destinado ao direito patrimonial dentro do direito de família (art. 1.639 e seguintes), bem como na localização textual dos artigos sobre união estável (art. 1723 e seguintes), muito após aquelas sobre o casamento. (BRASIL, 2002)

A família pós-moderna se pauta na desbiologização, na despatrimonialização, no afeto, sendo um meio para o pleno desenvolvimento de seus membros, mas a legislação recente não rompeu em definitivo com as características da família tradicional.

Diga-se que o Código Civil de 2002 (BRASIL, 2002) trouxe relevantes distinções patrimoniais em relação ao casamento e à união estável, especialmente no que diz respeito à sucessão, que era tratada com regime diferente daquele instituído aos cônjuges. $\mathrm{O}$ direito à sucessão dos companheiros era tratado no art. 1.790 do Código Civil, mas, o STF, ao julgar os Recursos Extraordinários 878.694 e 646.721, aprovou, em sede de repercussão geral a seguinte tese: "No sistema constitucional vigente é inconstitucional a diferenciação de regime sucessório entre cônjuges e companheiros, devendo ser aplicado em ambos os casos o regime estabelecido no art. 1.829 do Código Civil.”25 (CONJUR, 2017)

Assim como a Constituição, o Código Civil também não traz definição de família, apesar de seu art. 1.723, caput, ter sido usado de embasamento para aqueles que sustentaram a impossibilidade de o Supremo Tribunal Federal reco-

\footnotetext{
${ }^{24}$ Art. 1.611. O filho havido fora do casamento, reconhecido por um dos cônjuges, não poderá residir no lar conjugal sem o consentimento do outro.

${ }^{25}$ Contudo, "tal decisão não abrangeu a análise dos demais artigos que tratam do regime sucessório de cônjuges e companheiros, não tendo sido analisado, em especial, a integração constitucional do companheiro como herdeiro necessário" (LIMA, 2018, p. 75).
} 
nhecer a união estável homoafetiva e, portanto, a família homoafetiva, uma vez que sua infeliz redação, que reproduz o art. $226, \int 3^{\circ},{ }^{2627}$.

Como se esclarecerá a seguir, o STF entendeu que a redação de norma infraconstitucional (e até mesmo o texto literal da Constituição) não poderia superar os princípios e direitos constitucionais para impedir que homoafetivos formassem famílias.

A produção legislativa sobre o direito de família após a Constituição de 1988, como já mencionado, foi tímida, mas merece destaque a chamada Lei Maria da Penha - Lei 11.340/2006 (BRASIL, 2006), a qual foi mais um avanço na busca do objetivo de igualdade material entre homens e mulheres nas relações familiares ainda reconheceu de forma discreta a existência de relações familiares homoafetivas e da importância da proteção doméstica das mulheres, independentemente de sua orientação sexual ${ }^{28}$, sendo tamanha a sua relevância que sofreu três alterações legislativas apenas em 2019. ${ }^{29}$

Em razão do acirramento entre conservadores e defensores do conceito ampliativo de família no Congresso Nacional, após o advento do Código Civil de 2002 (BRASIL, 2002), houve poucos avanços na esfera legislativa federal no que diz respeito ao direito das famílias. Entre elas, podemos mencionar a Emenda Constitucional $n^{\circ} 66$ de 2010 (BRASIL, 2010), que alterou o $₫ 6^{\circ}$ do art. 226, para estabelecer que o casamento se dissolve com o divórcio. ${ }^{30}$

A ausência de uma definição expressa constitucional e infraconstitucional (que sempre deve seguir as premissas da Constituição) permite que mais configurações sejam abrangidas pelo conceito de família, se feita interpretação integrativa da Constituição. Desde a promulgação do texto constitucional, mo-

\footnotetext{
${ }^{26}$ Art. 226, \ $3^{\circ}$, CF: Para efeito da proteção do Estado, é reconhecida a união estável entre o homem e a mulher como entidade familiar, devendo a lei facilitar sua conversão em casamento. (grifo nosso)

${ }^{27}$ Art. 1.723, CC. É reconhecida como entidade familiar a união estável entre o homem e a mulher, configurada na convivência pública, contínua e duradoura e estabelecida com o objetivo de constituição de família

28 Art. 50 Para os efeitos desta Lei, configura violência doméstica e familiar contra a mulher qualquer ação ou omissão baseada no gênero que lhe cause morte, lesão, sofrimento físico, sexual ou psicológico e dano moral ou patrimonial [...] Parágrafo único. As relações pessoais enunciadas neste artigo independem de orientação sexual. (grifo nosso).

${ }^{29}$ Lei $13.827 / 2019$; Lei 13.836/2019 e Lei 13.894/2019.

30 A redação desse parágrafo é simples e ainda assim gerou diversos debates, especialmente acerca da revogação tácita da separação judicial: $\int 6^{\circ} \mathrm{O}$ casamento civil pode ser dissolvido pelo divórcio.
} 
delos familiares não expressamente abrangidos pelo texto passaram a ser objeto de demandas judiciais pelo seu reconhecimento.

\section{3 - O Papel do Judiciário - Interpretação e aplicação da Cons- tituição e da legislação infraconstitucional}

Se durante a segunda metade do século XX o Poder Legislativo se mostrou progressista (ainda que de forma morosa) no que se refere à ampliação do conceito de família e à diminuição da desigualdade entre homens e mulheres enquanto cônjuges e a filhos havidos ou não do casamento, possibilitando, ainda, a dissolução desse pelo divórcio, nas duas primeiras décadas deste século os avanços relevantes nessa seara foram decorrentes quase que exclusivamente de decisões do Poder Judiciário.

Após a promulgação da CF 1988, os questionamentos judiciais se mostraram variados, entre eles a já mencionada equiparação entre união estável e casamento na esfera sucessória, a possibilidade jurídica da existência de famílias paralelas, e a existência da família anaparental ${ }^{31}$ e da família homoafetiva.

O julgamento acerca da possibilidade jurídica de uniões estáveis homoafetivas e, consequentemente, de famílias homoafetivas foi definido pelo STF diante da ADIn 4277 e da ADPF 132. Por meio de uma análise guiada por um roteiro que desenvolvi em minha dissertação de mestrado, concluí que, por unanimidade de votos, o Supremo reconheceu a possibilidade de uniões entre casais do mesmo gênero, por meio de interpretação conforme a Constituição, superando a literalidade do parágrafo $3^{\circ}$ do art. 226, a fim de prestigiar princípios e direitos de maior relevância inseridos no próprio texto constitucional. Além disso, concluí que, por maioria de votos, os ministros entenderam que deveria ser aplicado à união estável homoafetiva o mesmo regramento jurídico conferido às famílias formadas heteroafetivas. Considerando que às uniões heteroafetivas estão assegurados o direito ao livre planejamento familiar, ao exercício da parentalidade e à conversão da união estável em casamento, esses direitos também estariam assegurados aos casais homoafetivos, sem possibilidade de retrocesso legislativo ou judicial sobre o tema.

\footnotetext{
31 O Superior Tribunal de Justiça reconheceu, em 2012, a existência da família anaparental (aquela formada por irmãos sem a presença de qualquer ascendente) e conferiu a ela proteção do Estado. STJ Terceira Turma - Relatora Min. Nancy Andrighi, Recurso Especial 1217415 / RS; DJe 28/06/2012.
} 
Essa conclusão é diferente da afirmação que fiz no artigo original, segundo o qual afirmei que estariam em aberto questões como o direito à adoção por casais homoafetivos. Contudo, após a análise feita na minha dissertação de mestrado do acórdão que reconheceu o direito à união estável homoafetiva pelo STF, concluí que, por decisão do Supremo, todos os direitos garantidos aos casais heteroafetivos seriam conferidos aos homoafetivos (LIMA, 2018, p. 182).

Para esse reconhecimento, o STF se pautou, em linhas muito resumidas, nos princípios constitucionais da dignidade humana, da promoção do bem de todos, na impossibilidade de discriminação por orientação sexual, que feriria os direitos à liberdade, à intimidade e à vida privada. Como descrito na ementa do acórdão, houve o "reconhecimento de que a Constituição Federal não empresta ao substantivo "família" nenhum significado ortodoxo ou da própria técnica jurídica" (fls. 612 da ADI 4277/DF).

O Supremo também se pautou no conceito de afeto (termo citado 37 vezes no acórdão) e de afetividade (citado onze vezes), reafirmando sua importância para a Corte.

O ministro relator, Ayres Britto, destacou o conceito de família baseado no afeto em seu voto, merecendo destaque os seguintes trechos em que analisa os desdobramentos do art. 226 da Constituição, cujo adjetivo usado pelo ministro é "emblemático":

Assim, o STF reconheceu a existência de uniões homoafetivas como família, sendo tal decisão oponível a todos. Diga-se que o julgamento foi pautado por ampla participação da sociedade, com diversos amici curiae (amigos da corte - entidades que se manifestam como auxiliares na formação do convencimento dos ministros), tendo participado entidades favoráveis ao reconhecimento da família homoafetiva, como o Instituto Brasileiro de Direito de Família (IBDFAM) e contrárias, como a Conferência Nacional Dos Bispos Do Brasil $\mathrm{CNBB}^{32}$

\footnotetext{
32 Diga-se que a relevância da ADI 4.277 e da ADPF 132 é inegável, mas esse julgamento foi precedido por longo debate legislativo, doutrinário e jurisprudencial sobre o tema. O PL 1.151/1995 da então Deputada Marta Suplicy visava disciplinar a união civil entre pessoas do mesmo gênero, há farto debate no meio acadêmico sobre o tema e o STJ se debruçou diversas vezes com a questão, havendo decisões de primeira instância que reconhecimento direitos patrimoniais a casais homoafetivos desde o final da década de 1990 (LIMA, 2018).
} 


\section{Disputa legislativa Os Projetos de Lei dos Estatutos da(s) Família(s)}

Como visto, o direito das famílias vem passando por profundas discussões possibilitadas pela ausência de definição legal definitiva sobre a composição da família e pelos diferentes entendimentos sobre esse tema.

Diante desse cenário, foram propostos nos últimos anos diversos projetos de lei sobre o tema. Por disputarem o conceito de família (mais ou menos ampliativo) o Estatuto das Famílias (PL 470/2013 do Senado) e o Estatuto da Família (PL 6.583/2013 da Câmara dos Deputados) ganharam destaque.

A semelhança no nome atribuído aos dois projetos de lei não foi coincidência: o Estatuto das Famílias propunha conceito ampliativo, ao passo que o Estatuto da Família propunha conceito tradicional, restritivo.

O Projeto de Lei do Estatuto das Famílias (PL do Senado 470/2013) desenvolvido pelo IBDFAM em parceria com a Senadora Lídice da Mata (PSB$\mathrm{BA}$ ), que o propôs, previa uma definição ampliativa de família: pelo texto se reconhece a consaguinidade (vínculo biológico), a afinidade (relações de parentesco decorrentes das relações de parentesco do cônjuge ou companheiro) e a socioafetividade ${ }^{33}$ como meios aptos a gerar vínculos de parentesco, o reconhecimento da família paralela, não falando em qualquer requisito como diversidade de gênero ${ }^{34}$.

Por sua vez, o Estatuto da Família - PL 6583/2013 (CÂMARA, 2013), proposto na Câmara dos Deputados em 16/10/2013 pelo Dep. Anderson Ferreira (PR-PE), previa que família fosse núcleo social formado a partir da união entre um homem e uma mulher, por meio de casamento ou união estável, ou ainda por comunidade formada por qualquer dos pais e seus descendentes. ${ }^{35}$

\footnotetext{
33 A filiação socioafetiva, em linhas bem gerais, seria formada pelo exercício de fato da figura de pai ou de um indivíduo, ainda que essas pessoas não tenham entre si vínculos biológicos ou de adoção. Os autores de direito de família passaram a desenvolver essa forma de criação de vínculo de filiação com base na teoria da desbiologização da parentalidade associada ao teor do art. 1593 do Código Civil de 2002 que prevê: O parentesco é natural ou civil, conforme resulte de consanguinidade ou outra origem. Assim, pautando-se na previsão legal de outras formas de origem de vínculos de parentesco além do biológico (indevidamente chamado de natural pele CC 2002) e da adoção (civil), deixou espaço para a existência de outras formas de parentesco.

34 Tramitou na Câmara dos Deputados o Projeto de Lei 674/2007 que também propunha Estatuto das Famílias, porém, após recursos da bancada evangélica, deixou de ter andamento.
} 
Ambos os projetos, Estatuto da Família e o Estatuto das Famílias deverão ser arquivados, já que não aprovados em todas as comissões ao final da legislatura de 2018.

Atualmente, nesse mesmo embate, estão em tramitação na Câmara dos Deputados os Projetos de Lei 3369/2015 (chamado de Estatuto das Famílias do Século XXI ${ }^{36}$, e os 4590/2019, 4824/2019, 4965/2019, 5162/2019, 5486/2019, 5541/2019 e 6309/2019 (todos esses últimos de mesma autoria e visam, com pequenas diferenças entre si, instituir o Estatuto das Famílias igualmente, preveem intervenção mínima do Estado e autodeterminação das famílias, mas consideram família apenas a união entre o homem e a mulher)

Ao se analisar os diferentes projetos de lei sobre a questão, mesmo os arquivados, (hoje não há mais o embate entre os nomes Estatuto da e das Famílias, Estatuto das Famílias, tanto os projetos que visam instaurar o conceito ampliativo quanto o restritivo usam o termo Estatuto das Famílias) fica evidente a polarização entre os congressistas e o embate frontal sobre o tema, mas causa consternação que ainda haja atividade legislativa tendente a excluir as pessoas do mesmo gênero do conceito de família já que as relações homoafetivas já ganharam seu reconhecimento definitivo pelo STF, por decisão vinculante, não passível de alteração por via legislativa ou judicial, como concluí em minha dissertação de mestrado

35 No curso desse debate, foi feita uma enquete que questionava: "Você concorda com a definição de família como núcleo formado a partir da união entre homem e mulher, prevista no projeto que cria o Estatuto da Família?". Essa enquete, sem qualquer compromisso com técnicas estatísticas, permitia que a mesma pessoa votasse diversas vezes, criando cenário de competição entre defensores e opositores do Estatuto da Família. Inicialmente, a enquete, assim como as demais existentes no site da Câmara permaneceria aberta até que ficasse sem registrar novos votos por determinado período. Porém, com mais de 10.000.000 (dez milhões de votos) ela foi encerrada, sendo o resultado final de $51,62 \%$ de votantes que não concordavam com a definição do Estatuto da Família, 48,09\% que concordavam e 0,29\% que não tinham opinião formada. Resultado Enquete conceito do núcleo familiar no Estatuto da Família. Disponível em:

< http://www2.camara.leg.br/enquetes/resultadoEnquete/enquete/101CE64E-8EC3436C-BB4A457EBC94DF4E;jsessionid =A454841BCD23F47AE2C694C4582DD12E.node1 >

36 Prevê intervenção do Estado mínima nas famílias, reconhecidas como "todas as formas de união entre duas ou mais pessoas que para este fim se constituam e que se baseiem no amor, na socioafetividade, independentemente de consanguinidade, gênero, orientação sexual, nacionalidade, credo ou raça, incluindo seus filhos ou pessoas que assim sejam consideradas." 
[...] há particularidades que permitem concluir que eventual superação do resultado da ADI 4.277/ADPF 132 somente pode se dar por ruptura das instituições políticas ou por nova Constituinte que preveja novo pacto constitucional, rompendo com o atual sistema. (LIMA, 2018, p. 180).

Eventual aprovação de qualquer projeto de lei excluindo os casais homoafetivos deverá, assim, ser declarado inconstitucional.

\section{Considerações finais}

A família é essencialmente uma unidade de conservação, tanto no sentido de proteção dos seres humanos, especialmente os mais vulneráveis, como no sentido de preservação de padrões e valores estabelecidos. Assim, ao longo do tempo ela é um instituto de disputa entre conservadores e progressistas, pois nela se afloram diversas questões ligadas a temas como igualdade entre homens e mulheres, pleno exercício da sexualidade, respeito à dignidade humana, autodeterminação das relações afetivas sexuais, entre outros.

Há claro embate entre correntes diferentes na sociedade e nos diferentes Poderes sobre o que é família. A família matrimonial, católica, branca, formada pelo homem, pela mulher e seus filhos, antes detentora do monopólio do conceito de família cedeu espaço a novas configurações familiares desde o início do século XX.

Os avanços no conceito de família, que continua a abarcar a família matrimonial, porém não mais de forma exclusiva, se pautam essencialmente no prestígio à dignidade humana. Além da expansão do conceito, 'dogmas' como a monogamia, dever de fidelidade, objetivo de procriação, entre outros passaram a ser questionados, inclusive juridicamente.

Se o Poder Legislativo vem se mostrando cada vez mais conservador sobre o direito das famílias, o Poder Judiciário, por meio da interpretação conforme a Constituição, ampliou esse conceito e superou até mesmo sua literalidade (art. 226, \ $3^{\circ}$, CF. BRASIL, 1988).

A despeito da polarização em torno do tema, a família, enquanto instituto jurídico, deve ser conceituada com base em critérios laicos (ou assim deveria ser), com igualdade entre seus membros, com o objetivo de permitir o pleno exercício da personalidade de cada um de seus integrantes.

Nesse sentido, a subversão do termo "naturalidade" para mascarar argumentos religiosos e ideológicos restritivos também deve ser afastada. Causa consternação que uma sociedade que se vangloria por se distanciar e superar os 
limites impostos pela natureza se apegue tanto ao argumento biológico para justificar conceito excludente de família (como impossibilidade de geração de prole).

Dessa forma, seus contornos dificilmente serão conceituados por meio de legislação em um futuro próximo, se é que isso é possível ou benéfico, sobretudo, diante da atual legislatura, reconhecida como conservadora, que foi precedida por quadro de parlamentares já tido como conservador ${ }^{37}$.

Como se nota, entre os três Poderes, o bastião da defesa da família plural, pautada também nos vínculos de afeto é, hoje, o Poder Judiciário. Entretanto, a judicialização do direito das famílias leva a desequilíbrio potencial entre os Poderes, sendo que avanços pelo Legislativo teriam mais legitimidade social e institucional. Entretanto, é reconhecido o caráter contramajoritário do Poder Judiciário (BARROSO, 2009, p. 383-384), por ser o único dos poderes cujos membros não são eleitos no Brasil por critérios eletivos.

Diante da análise feita, parece longe o dia em que o Legislativo cederá espontaneamente espaço à nova realidade social e à pluralidade familiar, de modo que a judicialização de demandas de cunho social relativas ao reconhecimento de formações familiares distintas da tradicional continuará a ser uma realidade nos próximos anos, causando ainda mais embate entre os poderes e críticas ao chamado ativismo judicial.

Enquanto aguardamos um Legislativo menos refratário a mudanças no conceito jurídico de família e vinculado a dogmas religiosos, cabe a reflexão: apesar da relevância social e jurídica do reconhecimento de direitos a relações humanas antes não reconhecidas como família, a tendência a ampliar o conceito de família e configurar diversas formas de relação humana não teria por si só um caráter também conservador, dado que essa é uma instituição tradicional e historicamente pautada em valores patriarcais, patrimoniais e religiosos?

37 CF. Congresso eleito é o mais conservador desde 1964, afirma Diap. Caderno Política. Estadão, 06 de outubro de 2014. Disponível em: http://politica.estadao.com.br/noticias/eleicoes, congresso-eleito-e-O-mais-

conservador-desde-1964-afirma-diap,1572528; Cientistas políticos veem perfil mais conservador na composição da Câmara. Câmara Notícia, 06 de outubro de 2014. Disponível em:

< http://www2.camara.leg.br/camaranoticias/noticias/POLITICA/475515CIENTISTAS-POLITICOS-VEEM-PERFIL-MAIS-CONSERVADOR-NA-

COMPOSICAO-DA-CAMARA.html>; Fragmentado, novo Congresso tem perfil conservador. Congresso em Foco, 01 de fevereiro de 2015.Disponível em: http://congressoemfoco.uol.com.br/noticias/fragmentado-novo-congresso-tem-perfilconservador/; Partidos Conservadores Avançam na Câmara. Estadão, 09 de outubro de 2018. 
Entretanto, ainda não propusemos academicamente ou juridicamente novas formas de proteção às infinitas e diferentes conformações de relações humanas e, diante da quantidade de demandas requerendo que suas relações sejam reconhecidas como família, parece se tratar uma demanda social o reconhecimento de que as relações humanas sejam reconhecidas como entidades familiares. Há, inclusive, situações de irmãs na Europa que querem se reconhecer como casal, pois assim teriam mais direitos do que apenas como irmãs ${ }^{38}$.

Quem sabe, no futuro, teremos uma constituição que reconheça as relações humanas como base da sociedade e merecedoras de especial proteção do Estado. Enquanto isso, o conceito ampliativo de família é um avanço progressista e um enfrentamento aos conservadores.

Porém, uma crítica final deve ser feita: a pouca apropriação pelos operadores do direito do conhecimento técnico de outras áreas, como a psicologia não trouxe efetivo diálogo entre os diferentes ramos do conhecimento. O surgimento de novos conceitos foi expressivo neste século XXI, multiparentalidade, poliamorismo, socioafetividade e ainda há muito que se discutir, sendo que o estudo jurídico e as decisões judiciais se tornarão cada vez mais fundamentadas e coerentes ao trazerem para perto outros ramos da ciência, especialmente quando envolvendo interesse de crianças e adolescentes, como na socioafetividade e na multiparentalidade, questões de ordem econômica (previdenciária, sucessória, alimentos) que não foram esgotados ou minimamente explorados de forma sistemática com suporte de outros ramos do conhecimento.

\section{Referências}

AZEVEDO, Á. V. Estatuto da Família de fato. São Paulo: Editora Jurídica Brasileira, 2001.

BARROSO, L. R. Curso de direito constitucional contemporâneo: os conceitos fundamentais e a construção do novo modelo. São Paulo: 2009.

BAUMAN, Z. Amor líquido: sobre a fragilidade dos laços humanos. Rio de Janeiro: Jorge Zahar, 2004.

BRASIL. Decreto N.1.144, de 11 de setembro de1861. Disponível em: $<$ https://www2.camara.leg.br/legin/fed/decret/1824-1899/decreto-1144-11setembro-1861-555517-norma-pl.html>. Acesso em: 20 jan. 2020.

38 A mulher que quer registrar uma união civil com a irmã. BBC New. Disponível em:<https://www.bbc.com/portuguese/geral-45744194> Acesso em: 4 out. 2018. 
. Lei ${ }^{\circ} \mathbf{1 0 . 4 0 6}$, de 10 de janeiro de 2002. Código Civil, 2002. Disponível em: < http://www.planalto.gov.br/ccivil 03/leis/2002/L10406compilada.htm>. Acesso em: 20 jan. 2020.

. Lei N $\mathbf{N}^{\mathbf{0}}$ 11.340, de 7 de Agosto de 2006. Lei Maria da Penha, 2006.

Disponível em: < http://www.planalto.gov.br/ccivil 03/ ato20042006/2006/lei/111340.htm >. Acesso em: 20 jan. 2020.

. Lei N. 3.071 de 01 de janeiro de 2016. Código Civil. 2016. Disponível em: < http://www.planalto.gov.br/ccivil_03/LEIS/L3071.htm > Acesso em: 20. jan. 2020.

-. Constituição da República Federativa do Brasil. 1988. Disponível em: $<\underline{\text { http://www.planalto.gov.br/ccivil 03/constituicao/constituicao.htm }>\text { Aces- }}$ so em: 20 jan. 2020.

. Emenda Constitucional n ${ }^{\circ}$ 66, de 13 de julho de 2010. Disponível em: <http://www.planalto.gov.br/ccivil 03/constituicao/Emendas/Emc/ emc66.htm >. Acesso em: 20 jan. 2020.

. Projeto de Lei N. 6583/2013. Dispõe sobre o Estatuto da Família e dá outras providências. Brasília, 2013. Disponível em: < https://www.camara.leg.br/proposicoesWeb/fichadetramitacao?idProposicao $=597005>$ Acesso em: 20 jan. 2020.

CONJUR. Cônjuges e companheiros têm os mesmos direitos de herança, decide Supremo. Conjur, 2017. Disponível em: <https:/ /www.conjur.com.br/ 2017-mai-11/conjuges-companheiros-mesmos-direitos-heranca-decide-stf $>$. Acesso em: 20 já. 2020.

CRUET, J. A Vida do Direito e a Inutilidade das Leis. Lisboa: Livraria Ed., 1908.

DIAS, M. B. Manual de direito das famílias. 8. ed. São Paulo: Revista dos Tribunais, 2011.

FARIAS, Cristiano C.; ROSENVALD, Nelson. Direito das Famílias. Rio de Janeiro: Lumen Juris, 2011.

FALEIROS, V. de P. Direitos da pessoa idosa: sociedade, política e legislação. In: DANTAS, B. et al.. (org.). Os cidadãos na carta cidadã. 1. ed. Brasília: Senado Federal, Instituto Legislativo Brasileiro, 2008, v. V, p. 562-592. Disponível em: <http://www12.senado.gov.br/publicacoes/estudos-legislativos/tipos-deestudos/outras-publicacoes/volume-v-constituicao-de-1988-o-brasil-20-anosdepois.-os-cidadaos-na-carta-cidada/idoso-pessoa-com-deficiencia-crianca-e- 
adolescente-direitos-da-pessoa-idosa-sociedade-politica-e-legislacao >. Acesso em: 10 nov. 2015.

FONSECA, J. P. da. Governo Bolsonaro não é conservador. My News, , 11 jul. 2019. Disponível em: < https://canalmynews.com.br/coluna-do-joel/ogoverno-bolsonaro-nao-e-conservador/> . Acesso em: 20 jan. 2010.

COUlAngES, N. a-D. F. de. A Cidade Antiga. São Paulo: Editora das Américas S.A. EDAMERIS, 1961. Disponível em: $<\underline{\text { http://www.ebooksbra- }}$ sil.org/eLibris/cidadeantiga.html\#n103 >. Acesso em: 05 nov. 2015.

GALVANI, G. Bolsonaro não é conservador. É um abusador midiático. Carta Capital, 04 jun. 2019. Disponível em: < https://www.cartacapital.com.br/politica/bolsonaro-nao-e-conservador-e-um-abusador-midiatico/>. Acesso em: 20 jan. 2020.

GIELOW, I. Casa só com 'mãe e avó' é 'fábrica de desajustados' para tráfico, diz Mourão. Folha de São Paulo, São Paulo, 17 set. 2018. Disponível em: $<$ https://www1.folha.uol.com.br/poder/2018/09/casa-so-com-mae-e-avo-efabrica-de-desajustados-para-trafico-diz-mourao.shtml>. Acesso em: 25 dez. 2019.

LAGO, M. Bolsonaro quer destruir o conservadorismo. Folha de São Paulo, São Paulo, 30 out. 2019. Disponível em: < https://www1.folha.uol.com.br/opiniao/2019/10/bolsonaro-quer-destruir-o-conservadorismo.shtml>. Acesso em: 20 jan. 2010.

LIMA, J. M. Família, contemporaneidade e conservadorismo: o direito das Famílias. In: MANDELBAUM, B.; SARAIVA, L. F. de O. Família, contemporaneidade e conservadorismos. São Paulo: Benjamin Editorial 2017. p. 115152.

A família homoafetiva na jurisprudência do STF e do STJ e sua contribuição à construção do conceito jurídico de família. 2018. 238 fls . Dissertação (Mestrado em Direito) - Faculdade de Direito. Universidade de São Paulo, 2018.

LÔBO, P. L. N. Direito civil: famílias. 4. ed. São Paulo: Saraiva, 2011.

. Direito de Família e os princípios constitucionais. In: PEREIRA, R. da C. (org.) Tratado de Direito das Famílias. Belo Horizonte: IBDFAM, 2015, p. 101-127.

MACEDO, F. Bolsonaro assina compromisso pela união entre homem e mulher. O Estado de São Paulo. São Paulo, 19 out. 2018. Disponível em: 
$<$ https://politica.estadao.com.br/blogs/fausto-macedo/bolsonaro-assina-compromisso-pela-uniao-entre-homem-e-mulher/> . Acesso em: 25 dez. 2019. MADALENO, R. Curso de direito de família. 6. ed. Rio de Janeiro: Forense, 2015.

PEREIRA, R. da C. Dicionário de Direito de Família e Sucessões: Ilustrado. São Paulo: Saraiva, 2014.

. Código Civil já nasce velho. Folha de São Paulo, São Paulo, 10 ago.

1996. Disponível em: < http://www1.folha.uol.com.br/fsp/1996/8/10/cotidiano/8.html >. Acesso em: 20 jan. 2020.

PONTES DE MIRANDA, F. C. Direito de Família: exposição técnica e sistemática do Código Civil brasileiro. Rio de Janeiro: Jachinto Ribeiro dos Santos, 1917.

POTTER, H. A trajetória política de Jair Bolsonaro. Carta Capital, , 26 out. 2018. Disponível em: < https://www.cartacapital.com.br/politica/a-trajetoriapolitica-de-jair-bolsonaro/>. Acesso em: 20 jan. 2020.

SARACENO, C.; NALDINI, M. Sociologia dela famiglia. Bologna: Il Mulino, 2013.

VEJA. TJ mantém condenação de Bolsonaro por resposta a Preta Gil e falas ao CQC. Veja, 10.05.2019. Disponível em: < https://veja.abril.com.br/politica/tjmantem-condenacao-de-bolsonaro-por-resposta-a-preta-gil-e-falas-ao-cqc/ $>$ Acesso em: 20 jan. 2020. 